\title{
ANTIBIOTIC SUSCEPTIBILITY PATTERNS AND PREVALENCE OF GROUP B STREPTOCOCCUS ISOLATED FROM PREGNANT WOMEN IN MISIONES, ARGENTINA
}

\author{
Quiroga, M. ${ }^{1}$; Pegels, E. ${ }^{1}$; Oviedo, P. ${ }^{1}$; Pereyra, E. ${ }^{2}$; Vergara, M. ${ }^{1}$ \\ ${ }^{1}$ Universidad Nacional de Misiones, Posadas, Misiones, Argentina; ${ }^{2}$ Hospital Dr. Ramón Madariaga, Posadas, \\ Misiones, Argentina
}

Submitted: July 31, 2007; Returned to authors for corrections: November 22, 2007; Approved: May 05, 2008.

\begin{abstract}
This study was performed to determine the susceptibility patterns and the colonization rate of Group B Streptococcus (GBS) in a population of pregnant women. From January 2004 to December 2006, vaginal-rectal swabs were obtained from 1105 women attending Dr. Ramón Madariaga Hospital, in Posadas, Misiones, Argentina. The carriage rate of GBS among pregnant women was $7.6 \%$. A total of 62 GBS strains were randomly selected for in vitro susceptibility testing to penicillin G, ampicillin, tetracycline, levofloxacin, gatifloxacin, ciprofloxacin, quinupristin-dalfopristin, linezolid, vancomycin, rifampicin, trimethoprimsulfametoxazol, nitrofurantoin, gentamicin, clindamycin and erythromycin, and determination of resistance phenotypes. No resistance to penicillin, ampicillin, quinupristin-dalfopristin, linezolid, and vancomycin was found. Of the isolates examined $96.8 \%, 98.3 \%, 46.8 \%$, and $29.0 \%$ were susceptible to rifampicin, nitrofurantoin, trimethoprim-sulfametoxazol and tetracycline, respectively. Rank order of susceptibility for the quinolones was: gatifloxacin $(98.4 \%)>$ levofloxacin $(93.5 \%)>$ ciprofloxacin $(64.5 \%)$. The rate of resistance to erythromycin (9.7\%) was higher than that of other reports from Argentina. High-level resistance to gentamicin was not detected in any of the isolates. Based on our finding of 50\% of GBS isolates with MIC to gentamicin equal o lower than $8 \mu \mathrm{g} / \mathrm{ml}$, a concentration used in one of the selective media recommended for GBS isolation, we suggested, at least in our population, the use of nalidixic acid and colistin in selective media with the aim to improve the sensitivity of screening cultures for GBS carriage in women.
\end{abstract}

Key-words: Group B Streptococcus, antibiotic susceptibility, prevalence, pregnant women, Argentina.

\section{INTRODUCTION}

Group B Streptococcus (GBS) is the most common cause of early-onset neonatal sepsis in developed countries (3).

Newborn acquire the organisms intrapartum from their mothers, who are colonized with GBS in the genital tract (41).

Different studies (10) reported that risk-based or screeningbased strategies recommended by the Centers for Disease Control and Prevention (CDC) had caused a significant decline in the prevalence of neonatal GBS infections $(9,41)$.

When public health decisions for implementing prevention strategies are needed, a basic point is the knowledge of the prevalence of maternal GBS colonization.
In Argentina, this prevalence varies widely between geographic areas and even between different populations. For instead, it was reported a maternal colonization rate of $1.4 \%$ in Cordoba, Argentina (29), 3.2\% in Rosario, Argentina (46), or 18.15\% in Jose de San Martin Clinical Hospital (22) and 9.39\% in Posadas Hospital (17), both of them situated in Buenos Aires, Argentina.

Dr. Ramón Madariaga Hospital is a public institution that serves primarily the uninsured residents of Posadas, the most important city of Misiones, a province situated in the northeaster of Argentina with strong boundaries with Paraguay and Brazil. Although Dr. Ramón Madariaga Hospital accounts for approximately $65 \%$ of the city's births, no data are available about the prevalence of maternal GBS carriers.

*Corresponding Author. Mailing address: FCEQyN-UNaM, Departamento Microbiología, Avenida Mariano Moreno 1375, Posadas-Misiones AR CP 3300. Tel.: 0054-3752-435118 Fax:0054-3752-435118. E-mail: marinaquiroga@fceqyn.unam.edu.ar 
Penicillin and ampicillin are the drugs of choice for prevention or treatment of GBS infections, and clindamycin and erythromycin are the recommended alternatives for patients who are allergic to $\beta$-lactam agents (41).

Widespread use of these antibiotics in various clinical conditions as well as their accepted efficacy of intrapartum prophylaxis in decreasing early-onset neonatal GBS infections has potentated the emergence of antibiotic resistance (27). Antibiotic resistance amongst GBS is considered an increasing problem so that it was recommended (31) to test the susceptibility of other antibiotics than those recommended as part to established control measures and that could be used as alternative choices for prophylaxis or treatment of GBS infection.

This study was performed to determine the colonization rate of GBS in a population of pregnant patients at Dr. Ramón Madariaga Hospital in Posadas, Misiones and the susceptibility patterns of the isolates to a variety of antibiotics.

\section{MATERIALS AND METHODS}

Bacterial isolates: From January 2004 to December 2006, vaginal-rectal swabs were obtained at 35 to 37 weeks of gestation from 1105 women attending at Dr. Ramón Madariaga Hospital in Posadas; Misiones who agreed to participate in this study.

During the study period, no protocol for prevention of GBS disease, such as routine testing of pregnant women, had been established in the maternity unit of the Hospital.

The samples were collected without speculum. The swabs were placed in Cary-Blair transport media (Difco, Argentina) and transported to the laboratory at room temperature for microbiology analysis. Swabs were inoculated in a selective broth medium, Todd-Hewitt broth supplemented with colistin $(10 \mu \mathrm{g} / \mathrm{ml})$ and nalidixic acid $(15 \mu \mathrm{g} / \mathrm{ml})$ (Laboratorios Britania, Argentina) and incubated at $37^{\circ} \mathrm{C}$ for 24 hours. The broths were then cultured on 5\% sheep's blood agar plates (Columbia agar base, Laboratorios Britania, Argentina). Culture plates were incubated at $37^{\circ} \mathrm{C}$ with $5 \% \mathrm{CO}_{2}$ for 24 hours. All suspected GBS colonies were sub-cultured and isolated for confirmatory testing. Biochemical standard methods were used to identify GBS (22). GBS identification was completed by group B-specific latex agglutination (Slidex Strepto-Kit, bioMérieux, Marcy l'Etoile, France)

Susceptibility testes: A total of 62 GBS strains were randomly selected for in vitro susceptibility testing. Susceptibility to penicillin G, ampicillin, tetracycline, levofloxacin, gatifloxacin, ciprofloxacin, quinupristin-dalfopristin, linezolid, vancomycin, rifampicin, trimethoprim-sulfametoxazol and nitrofurantoin was tested using microdilution panels (MicroScan, Dade Behring Inc, USA). Susceptibility to clindamycin and erythromycin and determination of resistance phenotypes were performed by the double-disk test on Mueller-Hinton agar (Biokar, France) supplemented with 5\% sheep blood (12). Disks of erythromycin $(15 \mu \mathrm{g})$ and clindamycin $(2 \mu \mathrm{g})$ were from Laboratorios Britania, Argentina. The different phenotypes of macrolide-lincosamidestreptogramin $\mathrm{B}\left(\mathrm{MLS}_{\mathrm{B}}\right)$ resistance were recognized as previously described (43). After $24 \mathrm{~h}$ of incubation at $35^{\circ} \mathrm{C}$, blunting of the clindamycin inhibition zone proximal to the erythromycin disk was taken to indicate inducible macrolidelincosamide-streptogramin $\mathrm{B}\left(\mathrm{MLS}_{\mathrm{B}}\right)$ resistance. Resistance to clindamycin with no blunting of the clindamycin inhibition zone indicated constitutive resistance. The M phenotype was characterized by susceptibility to clindamycin with no blunting of the inhibition zone around the clindamycin disk. The isolates were considered susceptible or resistant according MIC breakpoints recommended by the Clinical and Laboratory Standards Institute (CLSI) (12). The MIC of gentamicin (Bagó, Argentina) was determined by the agar dilution method according to the guidelines of the CLSI. High-level resistance to gentamicin was defined as a MIC of $\geq 500 \mu \mathrm{g} / \mathrm{ml}$.

\section{RESULTS}

84 of $1105(7.6 \%)$ women tested positive for GBS.

The susceptibilities of the 62 selected isolates to all antibiotics tested except gentamicin are summarized in Table 1. All GBS were susceptible to penicillin G, ampicillin, quinupristindalfopristin, linezolid, and vancomycin; and $29.0 \%$ were susceptible to tetracycline. $98.3 \%$ of the isolates were considered susceptible to nitrofurantoin, $96.8 \%$ to rifampicin, and $46.8 \%$ to trimethoprim-sulfametoxazol. Rank order of susceptibility for GBS for the quinolones was: gatifloxacin $(98.4 \%)>$ levofloxacin $(93.5 \%)>$ ciprofloxacin $(64.5 \%)$.

Of the 62 isolates, $2(3.2 \%)$ were resistant to clindamycin and $6(9.7 \%)$ were resistant to erythromycin. Among the erythromycin-resistant isolates, 2 expressed the inducible macrolide-lincosamide-streptogramin $\mathrm{B}\left(\mathrm{MLS}_{\mathrm{B}}\right)$ resistance phenotype, 2 the constitutive $\mathrm{MLS}_{\mathrm{B}}$ resistance phenotype and 2 the $\mathrm{M}$ resistance phenotype.

The gentamicin MIC ranged from 2 to $256 \mu \mathrm{g} / \mathrm{ml}, \mathrm{MIC}_{90}=64$ $\mu \mathrm{g} / \mathrm{ml}$ and $\mathrm{MIC}_{50}=8 \mu \mathrm{g} / \mathrm{ml}$. High-level resistance to gentamicin was not detected in any of the isolates.

\section{DISCUSSION}

GBS is an important cause of infection in pregnant women and their newborns in many countries, but there are still few data available from Latin America $(13,15,45,48)$. Maternal GBS colonization continues to be the most important risk factor for developing disease in the newborn (6). Implementation of rational GBS disease prevention protocols must be preceded by collection of data at the community level, due to variations in maternal GBS colonization in different populations (50). 
Table1. Antibiotic susceptibility profiles of group B Streptococcus isolated from pregnant women in Misiones, Argentina.

\begin{tabular}{|c|c|c|c|}
\hline \multirow[t]{2}{*}{ Antibiotic } & \multicolumn{3}{|c|}{$\begin{array}{l}\text { No. }(\%) \text { of the isolates with } \\
\text { indicated response }{ }^{\mathrm{a}}\end{array}$} \\
\hline & Susceptible & Intermediate & Resistant \\
\hline Penicillin $\mathrm{G}^{\mathrm{b}}$ & 100 & - & - \\
\hline Ampicillin $^{\mathrm{b}}$ & 100 & - & - \\
\hline Clindamycin ${ }^{\mathrm{b}}$ & 96.7 & - & 3.3 \\
\hline Erythromycin ${ }^{\mathrm{b}}$ & 90.2 & - & 9.8 \\
\hline Vancomycin ${ }^{\mathrm{b}}$ & 100 & - & - \\
\hline Tetracycline $e^{b}$ & 71.0 & - & 29.0 \\
\hline Rifampicin $^{\mathrm{c}}$ & 96.8 & 1.6 & 1.6 \\
\hline $\begin{array}{l}\text { Trimethoprim- } \\
\text { sulfametoxazol }^{\mathrm{c}}\end{array}$ & 46.8 & - & 53.2 \\
\hline Nitrofurantoin $^{\mathrm{d}}$ & 98.3 & 1.6 & - \\
\hline Gatifloxacin ${ }^{\mathrm{b}}$ & 98.4 & - & 1.6 \\
\hline Levofloxacin $^{\mathrm{b}}$ & 93.5 & 4.8 & 1.6 \\
\hline Ciprofloxacin $^{\mathrm{d}}$ & 64.5 & 32.3 & 3.2 \\
\hline $\begin{array}{l}\text { Quinupristin- } \\
\text { dalfopristin }^{\mathrm{b}}\end{array}$ & 100 & - & - \\
\hline Linezolid $^{\mathrm{b}}$ & 100 & - & - \\
\hline
\end{tabular}

${ }^{\mathrm{a}} \mathrm{n}=62$; ${ }^{\mathrm{b}} \mathrm{Clinical}$ and Laboratory Standards Institute (CLSI) breakpoint for Streptococcus spp. other than Streptococcus pneumoniae (12); ${ }^{\mathrm{c}}$ CLSI breakpoint for $S$. pneumoniae (12); ${ }^{\mathrm{d}}$ CLSI breakpoint for Enterococcus spp. (12).

The prevalence of maternal colonization by GBS depends on the culture methods, including the number and type of sites cultured and type of medium used, time of pregnancy, race, origin, age, parity and social-economic level (26). In Argentina the prevalence of GBS in pregnant women varies from 1 to $19 \%$ $(2,8,14,17,22,29,34,36,46)$.

The carriage rate of GBS among pregnant women in the present study was $7.6 \%$. Due to the differences of the population size and socio-economic status in each study, it is difficult to determine if the difference on GBS colonization rates between the Argentinean study groups are due to genetic differences between the populations or the uneven geographic distribution of GBS.

In this study neither penicillin-resistant nor intermediately penicillin-susceptible GBS strains were found as it was reported by different authors $(1,27,44)$.

At least in our population, penicillin or ampicillin remain the drugs of choice for intrapartum antibiotic prophylaxis for GBS colonization in pregnant women.

Penicillin is also the preferred choice for the treatment of infections caused by GBS. However, in vitro studies indicate that the rate of killing of GBS by these antibiotics is relatively slow compared with other streptococcal pathogens and have led some authors to recommend dual therapy using a penicillin plus gentamicin for severe GBS-associated infection (31). This approach requires the pathogen to be susceptible to both penicillin and aminoglycoside antibiotics. High-level resistance to aminoglycoside indicates that the isolate will not be affected synergistically by the combination of both antimicrobial agents. None of the strains tested in this study showed high-level resistance to gentamicin.

Erythromycin and clindamycin are the drugs of choice for women with serious penicillin allergy who are colonized with GBS (11). An increase in resistance of GBS to erythromycin has been reported $(5,18,25,32)$.

In our strains we found that 3.2 and $9.7 \%$ of the isolates were resistant to clindamycin and erythromycin, respectively. This rate of resistance to erythromycin was higher than that of other reports from Argentina like those of Lopardo et al. (5.2\%) (33), Pérez et al. (6.0\%)(39), Di Bartolomeo et al. (1.74\%) (17), García et al. (2.1\%) (22), and Mollerach et al. (2.4\%) (37), similar to that reported by Lermontov Borges et al. $(9.4 \%)$ in Brazil (30), but lower than reports from other countries $(16,19,27)$.

Resistance to erythromycin and clindamycin is caused by 2 main mechanisms in Streptococcus spp.: target site methylation of the 23S ribosomal component of the large (50S) ribosomal subunit and an active efflux pump. The methylases can be expressed constitutively or they can be inducible. This mechanism renders the bacteria resistant to most macrolide, lincosamide and streptogramin B compounds (MLS ${ }_{\mathrm{B}}$ phenotype). When the resistance mechanism due to active efflux is present, streptococci are resistant to macrolides, but susceptible to lincosamides and streptogramin B (M phenotype) (18).

$M$ and $\mathrm{MLS}_{\mathrm{B}}$ resistance phenotypes were observed in two and four erythromycin -resistant isolates, respectively. Other authors have highlighted the prevalence of $\mathrm{MLS}_{\mathrm{B}}$ resistance phenotype over M phenotype in GBS $(1,16,38,40)$.

Our study suggests that erythromycin and clindamycin resistance varied among geographic regions of Argentina. So that, for women who are allergic to penicillin the selection of an alternative prophylactic antibiotic should be guided by the antibiotic resistance patterns in each region. The rate of erythromycin resistance in GBS strongly supports the current CDC recommendation that antibiotic susceptibility testing should be performed if erythromycin or clindamycin therapy is needed to prevent neonatal GBS infection (25).

In agreement with other published studies all isolates tested in this study were susceptible to vancomycin $(4,38,44)$, quinupristin-dalfopristin and linezolid $(19,49)$.

We detected high percentages of tetracycline-resistant GBS. Our results were similar to those reported in Argentina (33) and those recorded in several studies performed in other countries $(20,35,47)$.

Resistance to quinolones has only recently been described for GBS (28). In our study we identified 1.6 and $6.5 \%$ of the 
isolates resistant to gatifloxacin and levofloxacin, respectively. As it was reported (23), gatifloxacin appeared to be more active than levofloxacin against GBS. As observed with pneumococci (21), our results find ciprofloxacin to be less active than the newer quinolones.

No resistance to nitrofurantoin was found in the GBS isolates tested by Simoes et al. (44). In this study, the susceptibility rate of nitrofurantoin was $98.3 \%$. We agree with these authors that nitrofurantoin could be a good option for the treatment of both asymptomatic and symptomatic bacteriuria caused by GBS.

Of interest is our finding of $50 \%$ of GBS isolates with MIC to gentamicin equal o lower than $8 \mu \mathrm{g} / \mathrm{ml}$ in light of a controversy which has existed concerning the use of gentamicin $(8 \mu \mathrm{g} / \mathrm{ml})$ in selective broth medium (7). At least in our population, our finding supports the position of García et al. (22) who recommended the use of nalidixic acid and colistin in selective media with the aim to improve the sensitivity of screening cultures for GBS carriage in women.

With more widespread use of antibiotics, selection of antibiotic-resistant GBS may occur. If resistance continues to be identified and increasing, surveillance of antibiotic resistance patterns among several antimicrobial classes will be important in determining optimal prophylaxis and treatment of GBS infections.

\section{RESUMO}

\section{Sensibilidade a antibióticos e prevalência de Streptococcus do grupo B em mulheres grávidas em Missiones, Argentina}

Esse estudo objetivou determinar os padrões de sensibilidade a antibióticos e as taxas de colonização de Streptococcus do grupo B (GBS) em uma população de mulheres grávidas. Entre janeiro de 2004 e dezembro de 2006, foram obtidos swabs vaginais-retais de 1105 mulheres no Hospital Dr. Ramon Madariaga, em Posadas, Missiones, Argentina. A positividade para GBS nas mulheres grávidas foi 7,6\%. Um total de 62 cepas de GBS foi selecionado ao acaso para testes in vitro de sensibilidade a penicilina $\mathrm{G}$, ampicilina, tetraciclina, levofloxacina, gatifloxacina, ciprofloxacina, quinupristinadalfopristina, linezolida, vancomicina, rifampicina, trimetoprimsulfametoxazol, nitrofurantoína, gentamicina, clindamicina e eritromicina, e determinação dos fenótipos de resistência. Não foi encontrada resistência à penicilina, ampicilina, quinupristinadalfopristina, linezolida e vancomicina. Entre as cepas, 96,8\%, $98,3 \%, 46,8 \%$ e $29,0 \%$ foram sensíveis à rifampicina, nitrofurantoína, trimetoprim-sulfametoxazol e tetraciclina, respectivamente. Para as quinolonas, a ordem de sensibilidade foi: gatifloxacina $(98,4 \%)>$ levofloxacina $(93,8 \%)>$ ciprofloxacina $(64,5 \%)$. A taxa de resistência à eritromicina $(9,7 \%)$ foi superior a de outros relatos na Argentina. Nenhuma das cepas apresentou alto nível de resistência à gentamicina. Devido a $50 \%$ das cepas de GBS terem apresentado MIC para gentamicina igual ou inferior a $8 \mathrm{mg} / \mathrm{ml}$, correspondente à concentração usada em um dos meios seletivos recomendados para GBS, sugeriu-se ao menos em nossa população, o emprego de ácido nalidíxico e colistina em meios seletivos para melhorar a sensibilidade da triagem de culturas para GBS em mulheres grávidas.

Palavras-chave: Streptococcus do grupo B, sensibilidade a antibióticos, prevenção, mulheres grávidas, Argentina.

\section{REFERENCES}

1. Aitmhand, R.; Moustaoui, N.; Belabbes, H.; Elmdaghri, N.; Benbachir, M. (2000). Serotypes and antimicrobial susceptibility of group B streptococcus isolated from neonates in Casablanca. Scand. J. Infect. Dis., 32 (3), 339-340.

2. Alaniz, A.D.; D’Agata, J.M.; Floridia, R.A.; Lara, C.S.; Melian, M.V.; Rodríguez, B.L.; Ruiz, B.B. (2005). Prevalencia de colonización por Streptococcus agalactiae en una población de mujeres embarazadas del Hospital Dr. Guillermo Rawson. Acta Bioquím. Clin. Latinoam. Suplemento 2, p.54.

3. American Academy of Pediatrics and Committee on Fetus and Newborn. (1997). Revised guidelines for prevention of early-onset group B streptococcal (GBS) infection. Pediatrics, 99, 489-496.

4. Andrews, J.I.; Diekema, D.J.; Hunter, S.K.; Rhomberg, P.R.; Pfaller, M.A.; Jones, R.N.; Doern, G.V. (2000). Group B streptococci causing neonatal bloodstream infection: antimicrobial susceptibility and serotyping results from SENTRY centers in the Western Hemisphere. Am. J. Obstet. Gynecol., 183 (4), 859-862.

5. Aracil, B.; Minambres, M.; Oteo. J.; De La Rosa, M.; Gomez-Garces, J.L.; Alos, A.J. (2002). Susceptibility of strains of Streptococcus agalactiae to macrolides and lincosamides, phenotype patterns and resistance genes. Clin. Microbiol. Infect., 8 (11), 745-748.

6. Baker, C.J.; Edwards, M.S. (2001). Group B streptococcal infections (Chapter 26). In: Remington, J.S.; Klein, J.O., (eds). Infectious diseases of the fetus and newborn infant. 5th Edition. W.B. Saunders Co, Philadelphia, USA, p.1091-1156.

7. Berkowitz, K.; Regan, J.A.; Greenberg, E. (1990). Antibiotic resistance patterns of Group B streptococci in pregnant women. J. Clin. Microbiol., 28 (1), 5-7.

8. Catan, M.A.; Caraballo, T.; Chianea, E.; Baldarene, C.; García, C.; Escalante, I. (2004). Aislamientos bacterianos en pacientes embarazadas con 35 a 37 semanas de gestación. XVII Congreso Latinoamericano de Microbiología, Buenos Aires, Argentina, E-266.

9. Centers for Disease Control and Prevention. (1996). Prevention of perinatal group B streptococcal disease: a public health perspective. $M M W R, 45$ (RR-7), 1-24.

10. Centers for Disease Control and Prevention. (1997). Decreasing incidence of perinatal group B streptococcal disease-United States, 1993-1995. MMWR, 46 (21), 473-477.

11. Centers for Disease Control and Prevention. (2002). Prevention of perinatal group B streptococcal disease. MMWR, 51, 1-22.

12. Clinical and Laboratory Standards Institute. (2006). Performance standards for antimicrobial susceptibility testing; sixteenth informational supplement. M100-S16. Wayne, PA.

13. Collins, T.S.; Calderon, M.; Gilman R.H.; Vivar, A.; Charache, P. (1998). Group B streptococcal colonization in a developing country: its association with sexually transmitted disease and socioeconomic factors. Am. J. Trop. Med. Hyg., 59 (4), 633-636.

14. Cotaimich, H.O.; Belbruno, G.; Torresi, E.; Nitardi. J.; Corte, M.; Vilches, G. (2004). Prevalencia de portación de Estreptococo beta- 
hemolítico del grupo B en gestantes de la ciudad de Río Tercero, Córdoba. XVII Congreso Latinoamericano de Microbiología, Buenos Aires, Argentina, E-265.

15. De Lourdes Collado, M.; Kretschmer, R.R.; Becker; I.; Guzmán, A.; Gallardo, L.; Lepe, C.M. (1981). Colonization of Mexican pregnant women with group B Streptococcus. J. Infect. Dis., (letter) 143 (1), 134.

16. De Mouy, D.; Cavallo, J.D.; Leclercq, R.; Fabre, R. and the AFORCOPI-BIO Network. (2001). Antibiotic susceptibility and mechanisms of erythromycin resistance in clinical isolates of Streptococcus agalactiae: French multicenter study. Antimicrob. Agents Chemother., 45, 2400-2402.

17. Di Bartolomeo, S.; Gentile, M.; Priore, G.; Valle, S.; Di Bella, A. (2005). Streptococcus agalactiae in pregnant women. Prevalence at the Posadas Hospital. Rev. Argent. Microbiol., 37 (3), 142-144.

18. DiPersio, L.P.; DiPersio, J.R. (2006). High rates of erythromycin and clindamycin resistance among OBGYN isolates of group B Streptococcus. Diagn. Microbiol. Infect. Dis., 54 (1), 79-82.

19. Fluegge, K.; Supper, S.; Siedler, A.; Berner, R. (2004). Antibiotic susceptibility in neonatal invasive isolates of Streptococcus agalactiae in a 2-year Nationwide Surveillance Study in Germany. Antimicrob. Agents Chemother., 48 (11), 4444-4446.

20. Fujita, K.; Murono, K.; Sakata, H.; Yoshioka, H. (1985). Susceptibility of group B streptococci to 30 antibiotics including new cephalosporins. Acta Paediatr. Jpn., 27, 247-252.

21. Fung-Tomc, J.; Minassian, B.; Kolek, B.; Washo, T.; Huczko, E.; Bonner, D. (2000). In vitro antibacterial spectrum of a new broadspectrum 8-methoxy fluoroquinolone, gatifloxacin. J. Antimicrob. Chemother, 45 (4), 437-446.

22. García, S.D.; Eiseth, M.C.; Lazzo, M.J.; Copolillo, E.; Barata, A.D.; de Torres, R.; Vay, C.A.; Famiglietti, A.M. (2003). Group B Streptococcus carriers among pregnant women. Rev. Argent. Microbiol., 35 (4), 183-187.

23. Gordon, K.A.; Beach, M.L.; Biedenbach, D.J.; Jones, R.N.; Rhomberg, P.R.; Mutnick, AH. (2002). Antimicrobial susceptibility patterns of beta-hemolytic and viridans group streptococci: report from the SENTRY Antimicrobial Surveillance Program (1997-2000). Diagn. Microbiol. Infect. Dis., 43 (2), 157-162.

24. Gray, B.M.; Pass, M.A.; Dillon, H.C. (1979). Laboratory and field evaluation of selective media for isolation of group B streptococci. J. Clin. Microbiol., 9, 466-470.

25. Heelan, J.S.; Hasenbein, M.E.; McAdam, A.J. (2004). Resistance of Group B Streptococcus to selected antibiotics, including erythromycin and clindamycin. J. Clin. Microbiol., 42 (3), 1263-1264.

26. Hickman, M.E.; Rench, M.A.; Ferrieri, P.; Baker, C.J. (1999). Changing Epidemiology of Group B Streptococcal Colonization. Pediatrics, 104 (2), 203-209.

27. Hsueh, P.R.; Teng, L.J.; Lee, L.N.; Ho, S.W.; Yang, P.C.; Luh, K.T. (2001). High incidence of erythromycin resistance among clinical isolates of Streptococcus agalactiae in Taiwan. Antimicrob. Agents Chemother, 45 (11), 3205-3208.

28. Kawamura, Y.; Fujiwara, H.; Mishima, N.; Tanaka, Y.; Tanimoto, A.; Ikawa, S.; Itoh, Y.; Ezaki, T. (2003). First Streptococcus agalactiae isolates highly resistant to quinolones, with point mutations in gyrA and parC. Antimicrob. Agents Chemother, 47 (11), 3605-3609.

29. Larcher, J.S.; Capellino, F.; De Giusto, R.; Travella, C.; Balagione, F.G.; Kreiker, G.; Cardona, H.P.; Zarate, A.; Vilaro, M.; Hernández, D.; Ruiz Orrico, G. (2005). Group B streptococcus colonization during pregnancy and prevention of early onset of disease. Medicina (Buenos Aires), 65 (3), 201-206.

30. Lermontov Borges, I.; Cerqueira d'Oliveira, R.E.; Dias de Castro, A.C.; Bona de Mondito, S.S. (2005). Streptococcus agalactiae in pregnant women: prevalence of colonization and antimicrobial susceptibility evaluation. Rev. Bras. Ginecol. Obstet., 27 (10), 575579 .
31. Liddy, H.; Holliman, R. (2002). Group B Streptococcus highly resistant to gentamicin. J. Antimicrob. Chemother, 50 (1), 142-143.

32. Lin, F.Y.; Azimi, P.H.; Weisman, L.E.; Philips, J.B.; Regan, J.; Clark, P.; Rhoads, G.G.; Clemens, J.; Troendle, J.; Pratt, E.; Brenner, R.A.; Gill, V. (2000). Antibiotic susceptibility profiles for Group B streptococci isolated from neonates, 1995-1998. Clin. Infect. Dis., 31 (1), 76-79.

33. Lopardo, H.A.; Vidal, P.; Jeric, P.; Centron, D.; Paganini, H.; Facklam, R.R.; The Argentinian Streptococcus Study Group; Elliott, J. (2003). Six-Month multicenter study on invasive infections due to Group B streptococci in Argentina J. Clin. Microbiol., 41 (10), 4688-4694.

34. Marramá, M.; de Olivera, A.; Ferreira, Y.; Botiglieri, M. (2004). Prevalencia de portación de Estreptococo $\beta$ hemolítico grupo "B" (EGB) en una clínica de la ciudad de Córdoba. XVII Congreso Latinoamericano de Microbiología, Buenos Aires, Argentina, E-263.

35. Melin, P.; Rodríguez-Cuns, G.; Fernández, W.V.; De Mol, P. (2000). Antimicrobial susceptibility of Streptococcus agalactiae isolated from patients in Belgium, 1989-1991 and 1996-1999. In: Martin, D.R.; Tagg, J.R. (eds.). Streptococci and streptococcal diseases. entering the new millennium. Proceedings of the XIV Lancefield International Symposium on Streptococci and Streptococcal Diseases. Securacopy, Auckland, New Zealand, p. 305-309.

36. Mendosa, M.A.; Morano, S.; Nardin, M.E.; Roldán, L.; Ahumada, C.; Mendez, E. (2004). Estreptococo grupo B: prevalencia de portación en embarazadas de dos centros de salud de Santa Fe. XVII Congreso Latinoamericano de Microbiología, Buenos Aires, Argentina, E-264.

37. Mollerach, A.; Mendez, E.; Massa, R.; Di Conza, J. (2007). Streptococcus agalactiae isolated in Santa Fe, Argentina: antibiotic susceptibility and erythromycin-clindamycin resistance mechanisms. Enferm. Infecc. Microbiol. Clin., 25 (1), 67-68.

38. Pearlman, M.; Pierson, C.L.; Faix, R.G. (1998). Frequent resistance of clinical group B streptococci isolates to clindamycin and erythromycin. Obstet. Gynecol., 92, 258-261.

39. Pérez, J.; Limansky, A.; Toresani, I.; Ebner, G.; Di Bartolomeo, S.; de Inocente, I.; Pretto, G.; Salazar, N.; Laferrara, M.; Bottiglieri, M.; Ballester, D.; Morales, M.; Rivera, L.; Cacace, M.L.; Castro, H.; Roldán, L.; Notario, R.; Borda, N.; Cera, G.; Spoletti, M.J.; Gregorini, E.; Sutich, E.G. (2004). Distribution of capsular types and antimicrobial susceptibility of Streptococcus agalactiae causing infections in Argentina. Rev. Argent. Microbiol., 36 (2), 63-67.

40. Portillo, A.; Lantero, M.; Olarte, I.; Ruiz-Larrea, F.; Torres; C. (2001). MLS resistance phenotypes and mechanisms in B-hemolytic group B, C and G Streptococcus isolates in La Rioja, Spain. $J$. Antimicrob. Chemother, 47, 115-116.

41. Schrag, S.; Gorwitz, R.; Fultz-Butts, K.; Schuchat, A. (2002). Prevention of perinatal group B streptococcal disease: revised guidelines from CDC. $M M W R, 51$ (RR11), 1-22.

42. Schuchat, A. (1998). Epidemiology of group B streptococcal disease in the United States: shifting paradigms. Clin. Microbiol. Rev., 11 (3), 497-513.

43. Seppala, H.; Skurnik, M.; Soini, H.; Roberts, M.C.; Huovinen, P. (1998). A novel erythromycin resistance methylase gene (ermTR) in Streptococcus pyogenes. Antimicrob. Agents Chemother., 42 (2), 257-262.

44. Simoes, J.A.; Aroutcheva, A.A.; Heimler, I.; Faro, S. (2004). Antibiotic resistance patterns of group B streptococcal clinical isolates. Infect. Dis. Obstet. Gynecol., 12 (1), 1-8.

45. Solorzano-Santos, F.; Echaniz-Aviles, G.; Conde-Glez, C.J.; CalderonJaimes, E.; Arredondo-Garcia, J.L.; Beltran-Zuniga, M. (1989). Cervicovaginal infection with group B streptococci among pregnant Mexican women. J. Infect. Dis., (letter) 159 (5), 1003.

46. Toresani, I.; Limansky, A.; Bogado, I.; Guardati, M.C.; Viale, A.; Sutich, E.G. (2001). Phenotypic and genotypic study of Streptococcus agalactiae in vagina of pregnant women in Argentina. Medicina (Buenos Aires), 61 (3), 295-300. 
47. Traub, W.H.; Leonhard, B. (1997). Comparative susceptibility of clinical group A, B, C, F, and G B-hemolytic streptococcal isolates to 24 antimicrobial drugs. Chemotherapy, 43, 10-20.

48. Trujillo, H. (1990). Group B streptococcal colonization in Medellin, Colombia. Pediatr. Infect. Dis. J., (letter) 9 (3), 224-225.

49. Tubau, F.; Fernandez-Roblas, R.; Linares, J.; Martin, R.; Soriano, F. (2001). In vitro activity of linezolid and 11 other antimicrobials against 566 clinical isolates and comparison between NCCLS microdilution and Etest methods. J. Antimicrob. Chemother., 47, 675-680.

50. Whitney, C.G.; Daly, S.; Limpongsanurak, S.; Festin, M.R.; Thinn, K.K.; Chipato, T.; Lumbiganon, P.; Sauvarin, J.; Andrews, W.; Tolosa, J.E.; Global Network For Perinatal And Reproductive Health. (2004). The international infections in pregnancy study: group B streptococcal colonization in pregnant women. J. Matern. Fetal Neonatal Med., 15 (4), 267-274. 